\title{
COMPETITION OR CONTROL VI: APPLICATION OF ANTITRUST LAWS TO REGULATED INDUSTRIES *
}

\author{
G. E. Hale $\dagger$ AND Rosemary D. HaLe $\ddagger$
}

Our inquiry has been designed to determine whether and to what extent the antitrust laws should be applied to regulated industries. For centuries the common law has recognized certain callings as affected with a public interest. Persons engaged in those callings are under a duty to serve all who apply for their products at reasonable prices. In modern times such duties have been crystallized in legislative enactments. As a result, in a wide variety of industries, governments fix prices, license entry, and control the services rendered. In most instances, however, there has been no express repeal, as to public utilities, of statutes forbidding monopolization and restraint of trade. They continue to exist side by side with interventionist measures. The need for reconciliation is patent.

Our initial study encompassed a wide range of regulated industries, from gas and water to insurance and banking. The courts apply the antitrust laws to many of such industries just as if entry were free, prices were uncontrolled, and services were beyond governmental sanctions. As to others, judges have perceived the conflict arising from the issuance of dual and often conflicting commands to the managers of regulated enterprises and have ruled that such businesses are expressly or impliedly exempt from the sweep of antitrust legislation. No consistent pattern, however, could be discerned in the decisions. ${ }^{2}$

* This is the sixth and concluding Article of the series. For prior installments see notes 1, 3-6 infra. George Miron, Esq., of the Department of Justice, kindly alerted the authors' attention to the case of Grand Jury Investigation of the Shipping Indus., 186 F. Supp. 298 (D.D.C. 1960).

$\dagger$ A.B. 1935, Yale University; LI.B. 1938, Harvard University; J.S.D. 1940, University of Chicago. Member, Illinois Bar.

$\ddagger$ A.B. 1940, Mount Holyoke College; M.A. 1946, American University. Lecturer in Economics, Lake Forest College.

1 Hale \& Hale, Competition or Contral I: The Chaos in the Cases, 106 U. PA. L. Rev. 641 (1958).

2 It might be thought that time lags would account for the continued application of the antitrust laws after imposition of regulation. In other words it may take some years for courts to realize that an industry is regulated or for regulation to become fully effective. Cf. Alderman, How Shall the Railroad Rate Structure be Regulated ist the Public Interest?, 12 LAw \& ConteMr. ProB. 579, 594 (1947). Perhaps such time lags are important factors in some industries but we have not found them to explain a substantial fraction of the cases. 
We next proceeded to a detailed examination of individual industries, beginning with radio and television broadcasting. ${ }^{3}$ Here we found strict control over entry into the field-imposed, however, ostensibly for other than economic purposes. We reviewed the efforts of the Federal Communications Commission to diffuse broadcast licenses over a large number of persons. We found that the FCC controls both the physical characteristics of transmission and the content of broadcast messages and imposes limitations on networks. But the absence of regulation in the vital area of prices and profits contributed to our conclusion that the antitrust laws could be applied to broadcasting despite active regulation under the Communications Act. The controls in question were primarily exercised to promote efficient transmission and not to protect the public from high prices or poor service.

We turned then to the field of motor carriers. ${ }^{4}$ Here a different picture was presented. Entry into competition is consciously restricted in order to protect those already in the field. Another important protection is the virtual prohibition against the entry of railroads into the trucking industry. Entry, once achieved, does not permit a carrier to operate in any territory or to carry any goods he pleases. His certificate is strictly limited to specified routes and named commodities and he must stay within the limitations of his class. An examination of transfers of certificates and mergers of trucking enterprises revealed that antitrust doctrines were not generally applicable. In the areas of service and rates, however, both state and federal commissions are largely helpless. While minimum rates are set as a further protection to enterprises already in business, reliance is placed solely upon competition both to maintain the quality of service and to keep maximum rates at reasonable levels. These surprising findings led to the conclusion that despite the inevitable confusion resulting therefrom, the antitrust laws should remain applicable to trucking enterprises. Otherwise the public would have no control over the vital matters of rates and services.

Our fourth study dealt with air carriers. ${ }^{5}$ In general, the pattern of control bears a marked resemblance to that of the trucking industry except that certain airlines are subsidized by the federal government. The subsidy feature, however, appears to be temporary and for that reason not controlling with respect to the applicability of the antitrust

3 Hale \& Hale, Competition or Control II: Radio and Television Broadcasting, 107 U. PA. I. REv. 585 (1959).

4 Hale \& Hale, Competition or Control III: Motor Carriers, 108 U. PA. L. REv. 775 (1960).

5 Hale \& Hale, Competition or Control IV: Air Carriers, 109 U. PA. L. Rev. 311 (1961). 
laws. A vital difference between air and motor carriage, however, does exist in the Civil Aeronautics Board's authority over services and rates. The CAB can compel the rendering of services, profitable or otherwise, and has power to fix maximum as well as minimum rates. As a consequence, there is no room for application of the antitrust laws to the airlines. Enforcement of such legislation would merely operate to impede the regulation of the industry by the CAB.

The final study concerned the production and distribution of electrical energy ${ }^{6}$ where the scope of regulation is so great as to render management virtually an agent of the regulatory commissions. To punish managerial behavior under the antitrust laws would constitute an indirect negation of administrative authority. Commissions control the industry in so pervasive a manner as to leave no room for the free play of competitive forces.

Thus, in the four regulated industries studied in detail, we found two in which exemption from the antitrust laws was indicated and two in which continued application of those statutes appeared necessary. The question now is whether those studies may form the basis for broad hypotheses concerning our central problem. Do they furnish a foundation for inclusive theory with respect to application of the antitrust laws to all regulated business? If so, what is the nature of the touchstone thus derived?

\section{Primary Jurisdiction}

In our first article reference was made to the doctrine of primary jurisdiction. ${ }^{7}$ That doctrine has often been used by courts to dispose of antitrust litigation when the subject matter appeared to lie within the peculiar responsibility of a regulatory agency. ${ }^{8}$ Frequently courts have utilized the doctrine to afford regulated business an implied exemption from antitrust control. Indeed the Supreme Court has referred to the doctrine in terms of an accomodation between antitrust laws and regulation:

That some resolution is necessary when the antitrust policy of free competition is placed beside a regulatory scheme involving fixed rates is obvious . . . Accordingly, this Court consistently held that when rates and practices relating thereto were challenged under the antitrust laws, the agencies had primary jurisdiction to consider the reasonableness of

6 Hale \& Hale, Competition or Control $V$ : Production and Distribution of Electrical Energy, 110 U. PA. L. Rev. 57 (1961).

7 Hale \& Hale, Competition or Control I, supra note 1, at 643 n.12.

8 But see California v. FPC, 369 U.S. 482 (1962), decided after our first Article was published, which casts doubt on the doctrine of primary jurisdiction. 
such rates and practices in the light of the many relevant factors including alleged antitrust violations, for otherwise sporadic action by federal courts would disrupt an agency's delicate regulatory scheme, and would throw existing rate structures out of balance. ${ }^{9}$

It cannot, however, be said that the courts have been wholly consistent in their application of the primary jurisdiction doctrine. For example, in a conspiracy action brought by a non-scheduled air carrier against certificated airlines seeking treble damages under section 4 of the Clayton Act, defendants' motion to dismiss on the ground that the $\mathrm{CAB}$ had primary jurisdiction was denied with the approval of the court of appeals. ${ }^{10}$ In the lower court it was said:

It is generally recognized that exemption from the antitrust laws must be secured in the precise manner and method prescribed by Congress . . . . The mere fact that a procedure is authorized whereby an immunity may be obtained does not require the imposition of primary jurisdiction of the $\mathrm{CAB}$ under the circumstances alleged in the complaint before us. ${ }^{11}$

Similarly, a railway equipment company brought an antitrust action against several railroads alleging a conspiracy to hold down the rate of compensation paid for the rental of its tank cars. ${ }^{12}$ It was alleged that, pursuant to the conspiracy, the defendants had filed tariffs with the ICC reflecting the low rentals. While the court referred the matter to the Commission to determine the proper amount of the rental, it refused to dismiss the case, saying:

It is the opinion of the Court that the defendants' contention that the complaint fails to state a claim is not well taken. The plaintiff pleads a conspiracy of the defendants which resulted in a diminution of the income derived from its rental

8 United States v. RCA, 358 U.S. 334, 348 (1959). See Federal Maritime Board v. Isbrandtsen Co., 356 U.S. 481, 496 (1958); Atchison T. \& S.F. Ry. v. Aircoach Transp. Ass'n, 253 F.2d 877, 886 (D.C. Cir. 1958) ; cf. Interstate Natural Gas Co. v. Southern Cal. Gas Co., 209 F.2d 380, 384 (9th Cir. 1953) ; Luckenbach S.S. Co. v. United States, 179 F. Supp. 605, 611-13 (D. Del. 1959), aff'd per curiam, 364 U.S. 280 (1960); Pacific Northwest Pipeline Corp., 31 P.U.R.3d 456, 460 (F.P.C. 1959). See generally Davis, Administrative Law Treatise $\$ 19.01$ (1958).

10 Slick Airways, Inc. v. American Airlines, Inc., 204 F.2d 230 (3d Cir.), cert. denied, 346 U.S. 806 (1953).

11 Slick Airways, Inc. v. American Airlines, Inc., 107 F. Supp. 199, 209 (D.N.J. 1951), aff'd, 204 F.2d 230 (3d Cir.), cert. denied, 346 U.S. 806 (1953); accord, Grand Jury Investigation of the Shipping Indus., 186 F. Supp. 298 305-07 (D.D.C. 1960); Hawaiian Airlines, Ltd. v. TransPacific Airlines, Ltd., 78 F. Supp. 1, 8 (D. Hawaii 1948); cf. Fitzgerald v. Pan Am. World Airways, Inc., 229 F.2d 499 (2d Cir. 1956). 1946).

12 Keith Ry. Equip. Co. v. Association of Am. Rys., 64 F. Supp. 917 (N.D. III. 
to the railroads of tank cars for the interstate transportation of liquid commodities. This is sufficient to state a cause of action under the Sherman Act. ${ }^{13}$

Primary jurisdiction, then, does not cause the transfer of antitrust actions in all instances from the courts to administrative tribunals. Moreover, it does not necessarily follow that antitrust principles will not be applied to those cases which are transferred to regulatory agencies. The administrative agency itself may be under a duty to apply antitrust standards. ${ }^{14}$ A gas pipeline operator, for example, applied to the FPC for leave to transfer use of the "Little Inch" pipeline from the transportation of gas to the hauling of petroleum. Haulers of oil by barge intervened and argued that the conversion would drive them out of business by reason of the destructive competitive power alleged to reside in the operator of the gas pipeline. The Commission allowed the conversion but the court of appeals reversed and remanded, ${ }^{15}$ saying:

Although the Commission has no power to enjoin conduct as illegal under the Sherman Act or even to declare such illegality, it certainly has the right to consider a congressional expression of fundamental national policy as bearing upon the question whether a particular certificate is required by the public convenience and necessity. ${ }^{16}$

We must not imagine, however, that the commissions have been directed wholly to abandon enforcement of their organic statutes and to take up the duties of the Attorney General and the Federal Trade Commission. Quite to the contrary, antitrust principles play but a limited role in commission decisions. The Supreme Court has said:

The very fact that Congress has seen fit to enter into comprehensive regulation of communications embodied in the Fed-

13 Id. at 920 ; accord, Riss \& Co. v. Association of Am. Rys., 170 F. Supp. 354, 365 (D.D.C.), aff'd sub nom. Atlantic Coast Line R.R. v. Riss \& Co., 267 F.2d 659 (D.C. Cir. 1959); cf. Packaged Programs, Inc. v. Westinghouse Broadcasting Co., 255 F.2d 708, 709-10 (3d Cir. 1958); Seatrain Lines, Inc. v. Pennsylvania R.R., 207 F.2d 255, 260 (3d Cir.), cert. denied, 345 U.S. 916 (1953).

14 Clayton Act $\$ 11,38$ Stat. 734 (1914), 15 U.S.C. §21 (1958).

15 City of Pittsburgh v. FPC, 237 F.2d 741 (D.C. Cir. 1956).

16 Id. at 754. Further proceedings are reported in Texas Eastern Transmission Corp., 17 F.P.C. 843 (1957) ; accord, Luckenbach S.S. Co. v. United States, 179 F. Supp. 605, 613-14 (D. Del. 1959), aff'd per curiam, 364 U.S. 280 (1960); cf. RCA Communications, Inc v. FCC, 238 F.2d 24, 27 (D.C. Cir. 1956), cert. denied, 352 U.S. 1004 (1957) ; Mansfield Journal Co. v. FCC, 180 F.2d 28, 33 (D.C. Cir. 1950); Isbrandtsen Co. v. United States, 96 F. Supp. 883, 889 (S.D.N.Y. 1951), aff'd per curiam by an equally divided Court sub nom. Rederi v. Isbrandtsen, 342 U.S. 950 (1952); Commercial Communications, Inc. v. Public Util. Comm'n, 50 Cal. 2d 512, 527-28, 327 P.2d 513, 522 (1958), appeal disntissed and cert. denied, 359 U.S. 341 (1959). 
eral Communications Act of 1934 contradicts the notion that national policy unqualifiedly favors competition in communications. ${ }^{17}$

The same Court has recently admonished the Interstate Commerce Commission that the antitrust laws do not constitute the appropriate measure of permissibility in considering the merger of two railroads. ${ }^{18}$ There is, in short, a bewildering array of authority with respect to the application of antitrust principles by regulatory commissions in which no coherent and consistent rationale can be discovered.

It is thus apparent that the doctrine of primary jurisdiction does not resolve all questions with respect to the application of the antitrust laws to public utilities. True, in many situations it results in the transfer of actions to commissions which disregard antitrust in favor of interventionist principles. The transfer, however, is far from automatic, ${ }^{19}$ and the doctrine is merely adjective in character because the commissions may still apply competitive doctrines to the regulated industries. The refusal of some courts to apply the doctrine of primary jurisdiction may be a reflection of dissatisfaction with just such an adjective disposal of a substantive problem.

\section{Toward Standards of Exemption}

Turning to the substantive question, the inquiry is whether standards can be set for the exemption of regulated industries from the antitrust laws. If regulation achieves the objectives of these laws, there is no reason to impose dual controls upon regulated industry. It is not easy, however, to state the objectives of the Sherman Act and related legislation.

Some observers think in terms of a "hard" competition model. The Sherman Act should eliminate all monopolies and restraints of trade, force prices down to levels close to marginal cost, and protect consumers through vigorous competition with respect to quality and

17 FCC v. RCA Communications, Inc., 346 U.S. 86, 93 (1953). The Court went or to state that "it is not too much to ask that there be ground for reasonable expectation that competition may have some beneficial effect. Merely to assume that competition is bound to be of advantage, in an industry so regulated and so largely closed . . . is not enough." Id. at 97.

18 Minneapolis \& St. L. Ry. v. United States, 361 U.S. 173, 186 (1959). See also McLean Trucking Co. v. United States, 321 U.S. 67, 83 (1944); Mackay Radio \& Tel. Co. v. FCC, 97 F.2d 641 (D.C. Cir. 1938); American Trucking Áss'n v. United States, 56 F. Supp. 394, 399 (E.D. Va. 1944), rev'd on other grounds, 326 U.S. 77 (1945) ; Pacific Northwest Pipeline Corp., 31 P.U.R.3d 456, 460-61 (FPC 1959). Note the striking decision in United States v. RCA, 358 U.S. 334 (1959), in which the Court held that the Commission was under a duty to consider the antitrust laws but that its decision on that issue had no binding effect.

19 See, e.g., Seatrain Lines, Inc. v. Pennsylvania R.R., 207 F.2d 255, 261 (3d Cir.), cert. denied, 345 U.S. 916 (1953). 
service. Barriers to innovation are to be swept away and entry into competition kept free at all times.

Others erect a model of "soft" competition under the antitrust laws, stressing protection of the weak against the strong. These observers, concerned lest vigorous firms drive the less fortunate from the field, are particularly anxious that no "unfair" practices result in elimination of companies already in business. They are anxious, too, that no "foreclosure" of competitors be accomplished by vertical integration or exclusive selling arrangements. ${ }^{20}$

Still a third group would apply a policy of pure laissez-faire. No impediments to innovation and dynamic progress would be tolerated. High profits obtained through monopoly or restraint of trade would be regarded as beneficial stimulants to giant steps forward in technology. ${ }^{21}$

The diversity of these three schools of thought demonstrates the confusion that exists with respect to the proper goals of antitrust legislation. We are left, therefore, with little in the way of a generally acceptable standard by which to measure the performance of regulatory commissions. ${ }^{22}$

Even if regulation were closely patterned on any one of the foregoing models, it would be difficult to discern whether appropriate results were being achieved. Under the doctrine of hard competition, for example, consumers are to be protected from high prices. ${ }^{23}$ Regulatory commissions do expend great effort in the fixing of rates at appropriate levels. We shall probably never know, however, whether those rates approximate the marginal cost to which prices would be driven under a regime of pure competition. And no matter how vigorously commissions may exercise powers over service, we can never be sure that the standards would not be higher were competition to prevail.

If "soft" competition be taken as the model, many actions of commissions can be cited as exemplifying its aims. Denial of entry to the "non-sked" air carrier in order to shield the airlines already in the field from new competition illustrates the protectionist philosophy which perrades many public utility industries. While little can be found to

20 Cf. United States v. Griffith, 334 U.S. 100 (1948); Packaged Programs, Inc. v. Westinghouse Broadcasting Co., 255 F.2d 708 (3d Cir. 1958); United States v. National City Lines, Inc., 186 F.2d 562, 567 (7th Cir.), cert. denied, 341 U.S. 916 (1951) ; Dirlam \& KaHN, Fair Competition 18, 276-77 (1954).

21 See, e.g., Schumpeter, Capitalism, Socialisy \& Dexiocracy 82-83, 88-89, 105 (3d ed. 1950); Hale \& Hale, Market Power 440-80 (1958).

${ }^{22}$ See, e.g., Adelman, The $A \& P$ Case: $A$ Study in Applied Economic Theory, 63 Q. J. ECoN. 238 (1949).

${ }_{23}$ Cf. Texas Eastern Transmission Corp., 17 F.P.C. 843, 851-52, 855-56, 858-59 (1957), in which the Commission refused to shelter barge line operators from pipeline competition, finding benefit to the public in the additional means of transport. 
indicate that the laissez-faire model of competition has guided regulatory commission, we can never be certain that laxity in enforcement of interventionist legislation does not achieve a substantially similar result.

It is, therefore, extremely difficult to ascertain whether and to what extent regulation achieves the goals which would otherwise be sought under the Sherman Act and related legislation. ${ }^{24}$ We are not sure of the standards we hope to achieve and cannot measure the agencies' achievement of them.

\section{Elimination of Conflict Between Antitrust ENFORCEMENT AND REgULATION}

Another possible means of reconciling the antitrust laws and regulatory legislation is to eliminate conflicts between them by removing one set of controls when it tends to nullify the other. If the antitrust laws directly interfere with a regulatory scheme, exemption should be found. Under such a test it is not necessary to measure degrees of monopoly power or to determine whether prices and service achieve optimum levels. Every antitrust complaint should be examined to determine whether granting the relief sought would directly impede operation of the regulatory scheme.

In such an effort, primary resort would, of course, be had to express exemptions appearing in the regulatory legislation. We need not pause to refer in detail to those express statutory exemptions, such as the McCarran Act in the field of insurance, ${ }^{25}$ and the Reed-Bulwinkle legislation applicable to railroad rate bureaus. ${ }^{26}$ While presenting delicate questions of interpretation, those exemptions may be regarded for present purposes as largely arbitrary in character and not indicative of general principles.

More instructive are decisions in which an implied exemption from the antitrust laws has been found. As one court said, such an

24 Note the contempt proceedings in Terminal Railroad Ass'n v. United States, 266 U.S. 17, 31 (1924). It had previously been held that the defendant railroads had violated the antitrust laws. 224 U.S. 383 (1912). Enforcement of the decree proved confusing for the courts and it was finally held that the matter lay within the jurisdiction of the ICC-an illustration, perhaps, of the wisdom embodied in the doctrine of primary jurisdiction.

2559 Stat. 33 (1945), 15 U.S.C. \$1011-14 (1958) ; see California League v. Aetna Cas. \& Sur. Co., 175 F. Supp. 857, 179 F. Supp. 65 (N.D. Cal. 1959); United States v. New Orleans Ins. Exch., 148 F. Supp. 915, 922 (E.D. La.), aff'd per curiam, 355 U.S. 22 (1957).

2662 Stat. 472 (1948), 49 U.S.C. \$ 4(b) (1958); cf. United States v. Railway Express Agency, 101 F. Supp. 1008, 1012-14 (D. Del. 1951). Note the narrow scope given express exemptions in Maryland \& Virginia Milk Producers' Ass'n v. United States, 362 U.S. 458 (1960) ; United States v. Pan Am. World Airways, Inc., 193 F. Supp. 18, 46 (S.D.N.Y. 1961), appeal granted, jurisdictional question reserved, 368 U.S. 964, 966 (1962). 
exemption is implied to the extent of the "repugnancy" between the antitrust laws and the regulatory statutes. ${ }^{27}$ The antitrust laws are deemed superseded by regulatory statutes lest the regulatory scheme be frustrated. But there is apparently a presumption against such implied exemptions as evidenced in the following statement from an air carrier case:

[I]n view of the importance of the antitrust laws to the unregulated part of the economy, the rule has been developed that the mere existence of a regulatory statute does not result in complete withdrawal of the regulated industry from the operation of the antitrust laws. Such repeals by implication are not favored. The antitrust laws have been held to be superseded by specific regulatory statutes only to the extent of the repugnancy between them. ${ }^{28}$

Therefore much depends on the type of regulation involved and the nature of the relief sought. It is necessary to test each allegation of an antitrust complaint against the specific type of regulation to determine whether a conflict exists between them. Courts have readily perceived that recovery of treble damages by private litigants could easily disrupt regulatory patterns. They may, for example, amount to a rebate prohibited by the regulatory statute. ${ }^{29}$ Similarly, an injunction directing the defendant to proceed in a manner inconsistent with regulatory legislation would directly nullify such intervention. ${ }^{30}$

Considerable difficulty, however, has been experienced in areas where administrative action has not yet been taken. Some years ago, for example, federal legislation provided a specific method of fixing the price of milk. Such price fixing, however, was discretionary with the Secretary of Agriculture and he had not seen fit to employ his powers. It was held that an antitrust action could still be maintained. ${ }^{31}$

27 Apgar Travel Agency v. International Air Transp. Ass'n, 107 F. Supp. 706, 711 (S.D.N.Y. 1952). A leading case is United States v. Hutcheson, 312 U.S. 219, 236 (1941). But cf. Allen Bradley Co. v. Local 3, Int'l Bhd. of Elec. Workers, 325 U.S. 797 (1945); United States v. Fish Smokers Council, 183 F. Supp. 227, 235-36 (S.D.N.Y. 1960).

28 S.S.W., Inc. v. Air Transp. Ass'n, 191 F.2d 658, 661 (D.C. Cir. 1951) ; accord, Silver v. New York Stock Exch., 196 F. Supp. 209, 220 (S.D.N.Y. 1961).

29 Keogh v. Chicago \& Northwestern Ry., 260 U.S. 156, 163 (1922) ; cf. Terminal Warehouse Co. v. Pennsylvania R.R., 297 U.S. 500, 514-15 (1936); Seatrain Lines, Inc. v. Pennsylvania R.R., 207 F.2d 255, 261 (3d Cir.), cert. denied, 345 U.S. 916 (1953); American Union Transp. v. River Plate \& Brazil Conference, 126 F. Supp. 91 (S.D.N.Y. 1954), aff'd per curiam, 222 F.2d 369 (2d Cir. 1955).

30 See Central Transfer Co. v. Terminal R.R. Ass'n, 288 U.S. 469, 475 (1933); Federal Broadcasting Sys. v. American Broadcasting Co., 167 F.2d 349, 352 (2d Cir.), cert. denied, 335 U.S. 821 (1948); Wheeling \& L.E. Ry. v.Pittsburgh \& W.V. Ry., 33 F.2d 390, 393 (6th Cir. 1929). But cf. Grand Jury Investigation of the Shipping Indus., 186 F. Supp. 298, 307-09 (D.D.C. 1960), a doubtful decision.

31 United States v. Borden Co., 308 U.S. 188, 198 (1939). Many fine distinctions can be drawn as to what constitutes sufficient exercise of interventionist powers. See, e.g., FTC v. Travelers Health Ass'n, 362 U.S. 293 (1960) ; FTC v. National Cas. Co., 357 U.S. 560, 564-65 (1958). 
It is apparent, therefore, that this allegation-testing approach leaves many questions unanswered. While some precedents have accumulated, it is difficult to determine in advance whether the courts will entertain proceedings under the Sherman Act and related legislation." The treble damages example is an obvious case of "repugnancy." But any relief under the antitrust laws may well interfere with the regulatory pattern established by a commission. ${ }^{33}$ Emphasis upon the precise remedy sought is at best a highly superficial test of the existence of an implied exemption.

If such an approach is unsatisfactory, an attempt might be made to set broad standards for determining the existence of conflicts between antitrust and interventionist legislation. We might first separate out non-economic interventionist control. In the field of broadcasting, for example, the allocation of a frequency is not designed to fix the price of advertising time over a television station. ${ }^{34}$ ICC control over safety of motor carrier operation is not primarily aimed at the maintenance of higher rates. Of course, such police power measures over health and safety may have a considerable impact upon economic matters, and it is easy to pervert police power control into protectionism. $^{35}$ Nonetheless, having eliminated non-economic intervention, we might seek to determine the existence of conflict by several tests. We could, for example, ask whether a considerable degree of discretion remained in the management of the regulated business. In the alternative, we might inquire whether competition remained a genuine possibility despite the imposition of interventionist control. Another approach would be to determine the degree of disturbance which antitrust enforcement would cause to the total regulatory scheme. ${ }^{36}$ But the difficulty with all these tests is simply that they require measure-

32 Note, for example, the distinctions drawn in the two opinions in California League of Independent Ins. Producers v. Aetra Cas. \& Sur. Co., 175 F. Supp. 857, 179 F. Supp. 65 (N.D. Cal. 1959). Note also the different results in Interstate Natural Gas Co. v. Southern California Co., 209 F.2d 380, 385 (9th Cir. 1953); In re American Fuel \& Power Co., 122 F.2d 223, 228 (6th Cir. 1941), involving pipelines. The matter is frequently passed ovcr without comment. See, e.g., Radiant Burners, Inc. v. Peoples Gas Light \& Coke Co., 364 U.S. 656 (1961).

33 See, e.g., ICC v. Oregon-Washington R.R., 288 U.S. 14, 28-29 (1933), wherein antitrust litigation put a halt for two decades to an extension of service later directed by the Commission. The courts, however, still pay little attention to such conflicts. See, c.g., United States v. Pan Am. World Airways, Inc., 193 F. Supp. 18, 47-48 (S.D.N.Y. 1961), appeal granted, jurisdictional question reserved, 368 U.S. 964, 966 (1962), wherein the court reiterated the old jibberish to the effect that there can be no antitrust exemption unless the regulatory tribunal is invested with power to grant the precise relief sought in the judicial proceeding.

34 Cf. United States v. Erie County Malt Beverage Distrib. Ass'n, 264 F.2d 731, 733 (3d Cir. 1959) (no fixing of liquor prices, hence no antitrust exemption). (1941)

35 See Hale, Principles of Free Enterprise, 1 Binl of Rights Review 186, 187-88

36 Texas \& Pac. Ry. v. Abilene Cotton Oil Co., 204 U.S. 426, 440 (1907) ; cf. Parker v. Brown, 317 U.S. 341, 352 (1943). 
ments which cannot be made. One of the studies in this series which sought to employ such standards reached the conclusion that the antitrust laws should be applicable to broadcasting. Nevertheless, the Attorney General, whose duty it is to enforce those laws, has written:

$[W]$ e observe that the concepts "regulation" and "free competition" . . . are antithetical. . . .

Maintenance of a completely competitive market requires that opportunity to enter that market be unrestricted. The telecasting business is not an industry in which unrestrained freedom to enter exists. . . . Consequently, the interpretation of the antitrust laws in cases involving telecasters must take into account the fact that entry is regulated by the Government. ${ }^{37}$

Yet another approach might be to classify regulatory schemes. A thorough effort to direct allocation of resources in economic channels, for example, would not seem to leave room for the play of competition. The difficulty, however, is to determine whether in fact an effort has been made to allocate resources on an economic basis. ${ }^{38}$ And even if this is the intent of the legislation, the actual regulation may fall short of the goal. At the opposite pole are types of regulation obviously undertaken to protect those already in the industry. Offhand, it would seem that such regulation would not constitute a bar to enforcement of the antitrust laws. Otherwise, there would be no limit to the industry's ability to exploit consumers. Here again, however, protectionism wears many guises and nothing less than a detailed examination of the entire regulatory pattern suffices to indicate whether consumers are protected or left at the mercy of the regulated enterprises. Thus the resource allocation-protectionism dichotomy provides an insufficient touchstone to determine whether regulated business should be exempt from antitrust laws. ${ }^{39}$ An interesting example of the confusion which can arise is found in a recent decision involving the behavior of an enterprise conducting a market for the sale of livestock. The opinion in the case squarely states that the stockyards company was a public utility. At the same time, it applies standards whereby the utility is forced to compete with others. ${ }^{40}$

37 Hearings Pursuant to S. Res. 13 and 163 Before the Scnate Committee on Interstate and Foreign Commerce, 84th Cong., 2d Sess. 404 (1956).

38 Cf. Pegrum, Economic Basis of Public Policy for Motor Transport, 28 LAND Econ. 244, 254-55 (1952).

$39 \mathrm{Cf}$. Stykolt \& Eastman, A Model for the Study of Protected Oligopolies, 70 EcoN. J. 336, 338 (1960). Many regulated firms are subsidized in cash or otherwise. If competition resulted in increased subsidies, taxpayers might well complain.

40 Denver Union Stock Yard Co. v. Producers' Livestock Marketing Ass'n, 356 U.S. 282, 288-89 (1958); accord, Montana-Dakota Util. Co. v. Williams Elec. Co-op., 263 F.2d 431, 433, 436 (8th Cir. 1959) (relying on old pre-regulatory decisions apply- 


\section{A Test Proposed}

Let us attempt a fresh start. We begin with the "mushroom" principle, a doctrine of economics to the effect that interventionist regulation must constantly expand. If the FPC is to control the price of gas from the pipe lines to local distributors, it must similarly control the price of gas at the wellhead. ${ }^{4 I}$ If the ICC is to control (protect) the railroads, it must exercise powers over motor carriers.

It has long been a commonplace of economic theory that intervention tends to feed upon itself. Each interference with the free play of the market sets up repercussions, which may also call for control, if the purpose of the original intervention is to be achieved. ${ }^{42}$

The mushrooming principle was vividly illustrated during World War II when interventionist controls were attempted throughout large segments of the economy. If prices were to be fixed; wages also had to be limited. One price or wage could not be left free for fear of its impact upon the others. Failure to reach out and control all economic activity might result in "distortions." If butter was to be rationed, butter substitutes could scarcely be overlooked. ${ }^{43}$

Recognition of the mushroom doctrine makes a detailed measure of the nature and scope of the controls exercised in a regulated industry less crucial. At any given moment those controls may not be sufficiently pervasive to warrant antitrust exemption. Under the mushroom doctrine, however, it is safe to assume that expansion will shortly take place; intervention will soon reach out to fill the gaps in the existing structure of controls; hence it is foolish to confuse matters by applying antitrust legislation in the interim. ${ }^{44}$ It would be difficult to

ing antitrust concepts more rigorously to public utilities than other businesses); Peoples Savings Bank v. Stoddard, 351 Mich. 342, 88 N.W.2d 462 (1958); cf. Yellow Cab Co. v. Chicago, 396 Ill. 388, 398-99, 71 N.E.2d 652, 657-58 (1947) ; Dairymen's League Co-op Ass'n v. Weckerle, 160 Misc. 866, 878, 291 N.Y. Supp. 704, 715 (Sup. Ct. 1936); Illinois Commerce Comm'n v. Panhandle Eastern Pipeline Co., 92 P.U.R. (n.s.) $370,381-82$ (Ill. Commerce Comm'n 1951).

41 Phillips Petroleum Co. v. Wisconsin, 347 U.S. 672 (1954).

42 Walker, War-time Econonic Controls, 58 Q.J. Econ. 503, 516 (1944).

43 Hale \& Hale, Monopoly \& Mobilization, 47 Nw. U.L. Rev. 606, 654-55 (1952); see Backaran, Governaent Price Fixing 263 (1938); Arpaia, The Attitude of the Several Forms of Transportation Toward Regulation, 20 ICC PRAC. J. 853 (1953); Caplan, Price Policy and Prodnction Controls, in Problems in Price Control. 475, 513 (1947) ; Daugherty, Wage Rate Control Standards, 41 AM. Econ. Rev. 63 (1951); Dewey, Transportation Act of 1940, 31 Am. Econ. Rev. 15, 16 (1941) ; Matheson, Decontrol Standards, in Problems in PRICE Control 7, 89 (1947); Shaw \& Tarshis, A Program for Economic Mobilization, 41 Am. Econ. Rev. 30, 36 (1951); Singer, The German War Economy, 51 EcoN. J. 400 (1941).

44 In view of the notoriously protracted nature of both antitrust and regulatory litigation it is difficult to conceive of either as a remedy for short-run ills. A fortiori no useful purpose could be served by applying both sets of controls in such a period of time. 
find in the current trend of political thought a general revival of free market thinking which might impede the progress of mushrooming.

Our thesis, then, is a simple one. Once true intervention has been decided upon, there is no further room for enforcement of antitrust legislation. It is not necessary to examine in detail the nature and scope of the regulatory measures or to ascertain to what extent they have been implemented by commission action. The mere existence of true intervention-and here we continue to distinguish police power regulation designed merely to protect public safety-is the signal for the abandonment of antitrust regulation.

Having proposed the foregoing principle, we must at once state an exception. There are instances in which practical limitations form a barrier to the mushroom principle. A vast number of regulated firms, for example, can constitute a substantial impediment to the effective extension of controls over them. ${ }^{45}$ In the case of motor carriersand no doubt the same is true of producers of natural gas-the ICC has had to leave public protection in the vital matters of service and price to competitive forces. ${ }^{46}$ It is not that such matters are beyond administrative competence. There is no reason why the ICC could not consider in detail the rate of each and every trucker in the United States, except that there are too many truckers. Due process of law requires that each trucker be allowed his day in court with pleadings, motions, evidence, cross-examination, and a decision upon a record duly made. It is clear that no commission could ever arrive at the proper rate to be charged for each and every commodity between each and every possible point of origin and destination within the country. Short cuts, of course, may be found; due process may be skimped or almost abandoned. ${ }^{47}$ The nature of regulation, however, requires that some consideration be given to the complex factual elements of cost; otherwise nothing approaching the desired results can conceivably be obtained.

\section{Conclusions}

We have suggested a new test for application of the antitrust laws to public utilities. The test is a simple one. If true interventionist

45 Lindahl, Federal Regulation of Natural Gas Producers, 46 Proc. Ax. Econ. Ass'v 532, 534 (1956). Munn, The Lesson of the Independent Gas Producer Regitlatory Experiment, 14 An. L. Rev. 40 (1961).

46 Hearings Before the Subcommittee on the Study of Monsopoly Power of the House Committee on the Judiciary, 81st Cong., 1st Sess., ser. 14, pt. 2-A, at 727-28 (1949) ; McMrllan, Individual Firm Adjustments Under OPA 24 (1949); TAfF, Commercial Motor Transportation 627 (1955) (thousands of tariffs published, cannot be examined individually by administration); Wallace, Price Control and Rationing, 41 Am. Econ. Rev. 60, 61 (1951). See also Ashbacker Radio Corp. v. FCC, 326 U.S. 327 (1945), stating a doctrine which has been widely applied in administrative proceedings. Cf. Jaffe, Standing to Secure Judicial Review, 75 Harv. L. REv. 255, 284 (1961).

47 See Yakus v. United States, 321 U.S. 414 (1944). 
legislation has been applied to a particular industry, we may assume, under the mushroom doctrine, that such intervention will rapidly spread, leaving no room for enforcement of the antitrust laws. An exception, however, is made when the regulatory burden is so great that effective control cannot be achieved. Here a true barrier to mushrooming may be found and, accordingly, room remains for application of antitrust principles either by courts or commissions.

The problem, therefore, is to determine whether the centripetal force of proliferation overcomes the centrifugal force of mushroomization. The centripetal force is most likely to consist of a high number of firms to be controlled. It also derives from the necessity of giving consideration to the claims of many other firms who, not yet controlled, seek entry into the regulated market or are affected by regulatory action.

Unless some principle such as that just outlined can be adopted, continuing confusion will ensue. In each case a fresh question will arise as to whether the industry is exempt from the antitrust laws. As we have seen, it does not appear possible to create broad standards for such exemption by determining whether regulation achieves approximately the same goals as a regime of pure competition. Furthermore, experience with a test based on "repugnancy" between antitrust laws and regulation has not been encouraging. In all too many industries today the possibility exists that dual controls, conflicting in character, will negate regulation and hinder proper administration of business. ${ }^{48}$

Ardent believers in antitrust policy may find the foregoing test in itself "repugnant." To them we suggest simply the magic word "repeal." 49 Much of the intervention now found in the American economy is not designed to protect consumers, but is often employed for the benefit of those ostensibly controlled. If chaos is to be avoided and resources allocated in an economic fashion it may prove desirable to eliminate much of the regulatory legislation now in our statute books, leaving room for sensible antitrust enforcement.

48 Cf. Dearing, The Reorganization of Transport Regulation, 40 AMr. Econ. REv. 261 (1950). But cf. Keyes, The Protective Functions of Commission Regulation, 48 Proc. Air. Econ. Ass'N 544 (1958). Mrs. Keyes writes:

The combination [of regulation and antitrust enforcement] is, however, entirely consistent with the nature of the transport markets of the real world, which are typically examples of monopolistic competition. Participant firms, though faced with competition which is real and valuable may be able to engage in restrictive practices and obtain sheltered positions in ways that are by definition ruled out where competition is pure; moreover, excess returns may persist even though artificial restrictions are eliminated as far as possible without disproportionate cost. In such markets, direct price control may well be a necessary supplement to competition strengthened by a procompetitive governmental policy. Id. at 545 .

Query whether Mrs. Keyes has assigned adequate weight to the cost of controls and, particularly, to the cost of reconciling contradictory commands.

49 See Becker, Competition and Democracy, 1 J.L. \& Econ. 105, 109 (1958). 